\title{
Human trafficking revisited: legal, enforcement and ethnographic narratives on sex trafficking to Western Europe
}

\author{
Brenda Carina Oude Breuil • Dina Siegel • \\ Piet van Reenen • Annemarieke Beijer • Linda Roos
}

Published online: 1 February 2011

(C) The Author(s) 2011. This article is published with open access at Springerlink.com

\begin{abstract}
In this paper we focus on the ways 'victims' and 'perpetrators' are imagined in the narratives on women who have been trafficked to West Europe for sexual exploitation. Three specific domains: international/national law, local law enforcement and ethnographic academic perspective are particularly important as they strongly influence political reaction to trafficking and describe the phenomenon from the perspective of the individuals concerned. In our analysis, an explanation of the diversity of the perceptions in these three domains is provided.
\end{abstract}

Keywords Human trafficking for sexual exlpoitation - 'Narratives' and 'imageries' . Legal definitions $\cdot$ Victims and perpetrator $\cdot$ Ethnography

\section{Introduction}

There are many different "stories" of human trafficking for sexual exploitation. Victims have written personal accounts of their experiences, ${ }^{1}$ often mediated by social workers from within "the rescue industry" - as Laura Agustín (2007) aptly calls the complex of welfare organizations concerned with the phenomenon. Neoconservative feminist lobbying groups frame their reflections in an emotionally outraged narrative ${ }^{2}$ and NGO's make strong appeals to the public concern and political decision-making when describing sex trafficking. The interpretations of national government agencies and law enforcement institutions reflect their sometimes conflicting interests in curbing irregular border passing whilst evading trespassing on international human

\footnotetext{
${ }^{1}$ See for example Akofa (2000) on labour exploitation and Mam (2005) on sexual exploitation

${ }^{2}$ See, for an elaboration of the role of these groups in defining trafficking in women and children: Ditmore (2005); Weitzer (2007) or Segrave et al. (2009).
}

B. C. O. Breuil $\cdot$ D. Siegel $(\bowtie) \cdot$ P. van Reenen $\cdot$ A. Beijer $\cdot$ L. Roos

Willem Pompe Institute, Utrecht University, Utrecht, The Netherlands e-mail: D.Siegel@uu.nl 
rights regulations. Religious groups add their moral claims to these definitions, and academic scholars supply the theoretical insights and biases of their disciplines.

All these groups of actors represent the phenomenon of human trafficking for the sex industry in different ways, depending on their organizational backgrounds, traditions, missions, needs and interests. From these specific socio-political, cultural and historical contexts spring different "narratives" and "imageries". 3 According to Charles Taylor (2002:106) 'ordinary people imagine their surroundings, and this is often not expressed in theoretical terms, but is carried in images, stories and legends'. The fact that there are multiple stories on sex trafficking does not mean that some of them are false or fiction (although they may contain fictitious elements), they are just differently embedded. Narrating human trafficking, in other words, refers to the way in which separate groups of actors shape "the truth" into a comprehensible, acceptable and productive story. Describing and dealing with human trafficking for the sex industry (and more generally: defining social problems per se) is, then, essentially a power struggle in which some actors or groups have greater power than others to enforce their narratives (as their perception of reality) onto others. Some will be able to have their meanings and interpretations institutionalized in laws and policies, while others will not (Becker 1991 [1963]: 17).

In this contribution, we focus on the ways "victims" and "perpetrators" are imagined in the narratives on women who have been trafficked to West European cities for exploitation in street prostitution. We have narrowed down our analysis to narratives circulating within three domains: international/national law, local law enforcement and academic ethnographic studies. These three areas are of particular importance, as the first two (the "legal narrative" and the "enforcement narrative") strongly influence the top-down, political approach of and a reaction to trafficking, whereas the third one (the "ethnographic narrative") aims at describing this phenomenon bottom-up, from the perspectives of the individuals concerned.

In our research ${ }^{4}$ we have analysed the legal narrative by way of an extensive literature study on the development of current legal ideas on human trafficking. We have included some critical notes on the international discourse made since 2005 by several social scientists (such as O'Connell Davidson 2005; Sanghera 2005; Weitzer 2007 and, more recently: Segrave et al. 2009). Although the European legal discourse does not follow the larger, international discussions fully, the latter do influence the European discourse and therefore seem relevant to discuss here. As far as the translation of international legal discourse into a local legal imagination is concerned, we have narrowed down our analysis to one case-study: that of the Netherlands. This focus has been continued in our analysis of the enforcement narrative, for which we have conducted a limited number of expert interviews, used data from an expert meeting ${ }^{5}$ and a (national) thematic meeting of a task force on Human Trafficking, ${ }^{6}$ studied written documents of the Royal Dutch Police and

\footnotetext{
${ }^{3}$ For a similar approach to narratives and imageries, but applied to the politics of transnational organized crime, see Edwards and Gill (2002).

${ }^{4}$ This article is based on interdisciplinary study within the framework of the 'Focus and Mass Programme Conflict and Human Rights' of Utrecht University, the Netherlands.

${ }^{5}$ Expert meeting entitled "Human Trafficking Imagined", Willem Pompe Institute of Criminal Law and

${ }^{6}$ Leiden, Holiday Inn Hotel, October 29, 2009
} 
newspaper clippings, in order to get insight into the social imaginations on victims and perpetrators of human trafficking within the Dutch Police force. The analysis of the ethnographic narrative is based on literature research, as well as on empirical researches conducted by the authors themselves (e.g. Oude Breuil 2008; Roos 2008 and Siegel 2005, 2007).

Jyoti Sanghera (2005: 4) already pointed out in 2005 the poor empirical basis of most trafficking research. Notwithstanding the "hype"-status of the phenomenon in media and policy debate in the last few years, this situation has not significantly improved, according to Sheldon Zhang (2009: 185): 'imagination seems to have taken the place of sound empirical studies.' This lack of empirical evidence, however, does not stop researchers and advocacy groups from making policy recommendations (ibid: 185) which may eventually be translated into enforcement strategies. As several other authors have shown, policy and law enforcement perspectives on human trafficking often depart from a black-and-white picture of helpless, innocent and naïve victims (e.g. O'Connell Davidson 2005; Sanghera 2005; Agustín 2007; Janssen 2007; Oude Breuil 2008 et cetera). Empirical research could enlighten, according to Zhang (2009: 191), the question of how trafficking victims negotiate their work and exert agency within situations of coercion. The interdisciplinary approach we present here, offers a dual focus on agency and structure, which is often lacking in single-disciplinary studies. Including empirical data on which the ethnographic narrative is based, allows one to combine the often fragmented and contradictory images of human trafficking, which are a result of different approaches and ideas within various disciplines. With this contribution we aim at enlightening the specific (theoretical, ideological or empirical) biases in these different narratives, as well as showing how the legal and law enforcement narrative might profit from including sound ethnographic data into their often stereotypical images of victims and perpetrators of human trafficking.

\section{The legal narrative: historical legacy}

According to the anthropologist Clifford Geertz '(...) the "law" side of things is not a bounded set of norms, rules, principles, values, or whatever from which jural responses to distilled events can be drawn, but part of a distinctive manner of imagining the real.' (Moore 2005: 18, emphasis added). In this section we examine how international treaties have come to imagine trafficking in human beings for sexual exploitation. How were images of perpetrators and victims constructed within these treaties?

The definition of trafficking in human beings has shifted over time. In the $1880 \mathrm{~s}$ strong public concern about European girls (mainly from Belgium, Germany and Great Britain) being trafficked within Western Europe to be put to work in brothels was expressed in the concept of "white slavery", a phenomenon strongly associated with "innocent" girls being misled by traffickers. The girls were supposed to end up in prostitution against their will (Haveman 1998: 100-114; Kempadoo 2005: x; Segrave et al. 2009: 1).

In 1904 several European states signed the International Agreement for the Suppression of the White Slave Traffic (Paris, 18 May 1904) aiming at outlawing the 
recruitment of women for sex work by means of force or deceit. Forty-five years later the scope of trafficking was broadened and thereby the image of the victim was elaborated; the 1949 UN Convention for the Suppression of the Traffic in Persons and of the Exploitation of the Prostitution of Others obliged states to punish a person who 'to gratify the passions of another, procures, entices or leads away, for purposes of prostitution, another person, even with the consent of that person.' The image of the victim changed in the sense that now men were also considered as potential victims of trafficking. Furthermore, the consent of the victim was no longer relevant as a prerequisite to convict the perpetrator. Although this convention superseded earlier agreements and became the new standard, only a few states ratified it, mainly because of the Convention's abolitionist ${ }^{7}$ approach to prostitution.

As a political issue, trafficking disappeared from the international agenda until the $1970 \mathrm{~s}$ and up to the $1980 \mathrm{~s}$ when international tourism, changing sexual mores and the international emergence and awareness of the aids epidemic renewed the need for political attention. Important actors in the political debates were second wave radical feminists who opposed what they called "sexual slavery", which was considered the result of patriarchal oppression (Kempadoo 2005; Segrave et al. 2009). This radical feminist discourse, also known as the sexual domination discourse, considers prostitution to be forced by definition and thus a matter of slavery. Trafficking and prostitution are intrinsically linked in this discourse; women who migrate and end up in the sex industry are perceived to be victims of trafficking per se (Kempadoo 2005; O'Connell Davidson 2005; Segrave et al. 2009). The proponents of this perspective strived (and still strive) for the abolition of prostitution.

In opposition to the abolitionists, the so-called "sex work" approach emerged, which considers prostitution to be a legitimate profession, a manner to earn a living. Prostitution, in this regard, is not perceived as a social problem per se; it depends on the labour conditions under which it takes place whether or not prostitution is a matter of exploitation. Trafficking in human beings for the sex industry is, in this perspective, first of all considered as a form of labour migration. The "fight against trafficking" is mainly seen as a fight against forced prostitution and proponents of this approach strive for the improvement of working conditions in the sex industry (Outshoorn 2005; Kempadoo 2005; Segrave et al. 2009). In contemporary debates on human trafficking for the sex industry, we can still recognize a polarisation between the abolitionist and the sex work position (Segrave et al. 2009), whereby the abolitionist discourse has dominated legislation resulting from the trafficking debates (Outshoorn 2005). This accounts for United Nations legislation more than for European Union legislation, as we will see in the next section.

With the 1993 Vienna Declaration and Programme of Action of the World Conference on Human Rights, a first shift away from abolitionism was made. The declaration no longer focussed on prostitution per se but on forced prostitution and trafficking. The 1995 Platform for Action adopted at the Beijing UN Women's World Conference focussed on fighting forced prostitution and trafficking (Outshoorn 2005). From 1998 onwards, trafficking and prostitution have become part of the battle against transnational organized crime, which is reflected in the fact that the

\footnotetext{
${ }^{7}$ For a good description of the abolitionist perspective (as opposed to the "sex work" perspective) on prostitution see, for example: Segrave et al. (2009: 1-7)
} 
Protocol to Prevent, Suppress and Punish Trafficking in Persons, Especially Women and Children (commonly referred to as the "Palermo Protocol", December 15, 2000) is a supplement to the UN Convention against Transnational Organized Crime (O'Connell Davidson 2005: 71; Kapur 2005: 33-35). As international concerns have increasingly focussed on the "threat" of transnational organized crime and the protection of national borders, trafficking in human beings has essentially become a matter of law and order: 'the response to trafficking in persons emphasized the proximity of this issue to other irregular migration issues and illicit cross-border activities' (Segrave et al. 2009: 18).

Trafficking in human beings is thus traditionally seen as a problem related to prostitution and illegal migration. As a result of fierce lobbying by NGO's and civil groups, trafficking in human beings is nowadays increasingly reframed as a human rights issue, especially so within the European discourse.

\section{The UN trafficking protocol and two important European legal instruments}

The UN Protocol to Prevent, Suppress and Punish Trafficking in Persons, Especially Women and Children, Supplementing the United Nations Convention against Transnational Organized Crime, commonly referred to as the "Palermo Protocol" (hereafter: UN Trafficking Protocol), is today the most important international legal instrument on human trafficking as it contains the first widely accepted definition of trafficking. The emphasis on women and children reflects a gendered stereotype; women are supposed to be victims, men are perceived as perpetrators. Moreover, the Protocol presents a focus on a particular type of trafficking, namely well organised trafficking by international crime networks (see also: Sanghera 2005:15). The UN Trafficking Protocol does not reflect, however, the actual knowledge on the variety of types of networks implied in trafficking, varying from highly organised, international organisations to small, flexible networks operating between only two or several countries and strongly locally based.

The European Union imaginations on trafficking in human beings seem to be more elaborate and up-to-date than those of the UN Trafficking Protocol. The former recognise that trafficking can be transnational or national, linked to organised crime but not necessarily so. The European Union definition of trafficking applies to both men and women, although it is recognised that women are the most important targets of traffickers. The legal definition of the European Framework Decision ${ }^{8}$ is thus remarkably broad, which is in accordance with the heterogeneous cases of trafficking in human beings for sexual exploitation (e.g. Herz 2005).

However, the definition reflects more narrow, normative and populist notions as well. The Council of Europe associates trafficking with the historical Atlantic slavetrade, as can be seen from the following wording: '(it) treats human beings as a commodity to be bought and sold, and to be put in forced labour, usually in the sex industry (...)'. 9 The equation with the earlier slave-trade invokes a forceful, emotionally-loaded historical memory (Kempadoo 2005: xix), which may hinder

\footnotetext{
${ }^{8}$ Framework Decision on combating trafficking in human beings, 19 July 2002, PbEGL 203.

${ }^{9}$ Council of Europe Convention on Action against Trafficking (CETS no. 197), Explanatory Report, Introduction, par. 3 .
} 
the analysis of the phenomenon. Seeing sex trafficking as slavery, moreover, allows for the use of 'conceptual binaries that are held dear in liberal democracies [:] Adult/ Child, freedom/slavery, civilized/barbaric, virtuous woman/whore (...)'. These binaries do not necessarily reflect the experiences, nor are they in the interest of trafficked persons themselves (O'Connell Davidson 2005: 42).

The Framework Decision of the European Union aims at the criminalization of trafficking, the harmonization of national laws on trafficking and the protection of victims. In article 2 it defines trafficking in human beings as follows ${ }^{10}$ :

"Trafficking in human beings" shall mean the recruitment, transportation, transfer, harbouring or receipt of persons, by means of the threat or use of force or other forms of coercion, of abduction, of fraud, of deception, of the abuse of power or of a position of vulnerability or of the giving or receiving of payments or benefits to achieve the consent of a person having control over another person, for the purpose of exploitation. Exploitation shall include, at a minimum, the exploitation of the prostitution of others or other forms of sexual exploitation, forced labour or services, slavery or practices similar to slavery, servitude or the removal of organs'.

The Explanatory Memorandum on the Framework Decision shows that the makers were aware of the fact that the line between coercion and voluntariness is not always easy to draw. According to the Explanatory Report, some trafficked persons do not know what is in store for them while others are perfectly aware that they will be engaging in prostitution when leaving their countries of origin. However, being willing to engage in prostitution does not automatically mean consenting to be subjected to abuse of all kinds. To avoid such complications, the Framework Decision regulates that if one of the means mentioned in article 1 was used, it is irrelevant whether the victim agreed to the exploitation.

The central element of the description of human trafficking in the Framework Decision (article 2) is "exploitation". The following phrase from the Explanatory Report makes clear which picture the drafters of the Framework Decision had in mind when they refer to exploitation.

"In short, the situation can be any state of hardship in which a human being is impelled to accept being exploited. (...) A wide range of means therefore has to be contemplated: abduction of women for sexual exploitation, enticement of children for use in paedophile or prostitution rings, violence by pimps to keep prostitutes under their thumb, taking advantage of an adolescent's or adult's vulnerability, whether or not resulting from sexual assault, or abusing the economic insecurity or poverty of an adult hoping to better their own and their family's lot. However, these various cases reflect differences of degree rather than any difference in the nature of the phenomenon, which in each case can be classed as trafficking and is based on use of such methods"11

\footnotetext{
${ }^{10}$ Framework Decision on combating trafficking in human beings, 19 July 2002, PbEGL 203.

${ }^{11}$ The definition in the Framework Decision on human trafficking and that of the Convention against trafficking of the Council of Europe are the same, see: Council of Europe Convention on Action against Trafficking (CETS no. 197), article 4 and the Framework Decision of 19 July 2002 on combating trafficking in human beings, article 2 .
} 
According to the European Union the vulnerability of victims for exploitation may thus be attributed to a number of circumstances including economic, emotional, physical or psychological circumstances.

\section{The implementation of the international and European legal narratives in Dutch law}

Even though international legal instruments aim at achieving more widely shared legal approaches to trafficking in human beings, national laws are still, to a large extent, local laws, inspired by local norms, values, traditions and interpretations of prostitution and (illegal) migration. Such local interpretations determine to some extent how trafficking for sexual exploitation is reacted to, and how international legal images are locally coloured. National (and culturally and historically-anchored) attitudes and policies on prostitution and illegal immigration, as well as the way former laws were drafted, thus account for variations in legal interpretations of sex trafficking. Therefore, even within Europe, one cannot speak of one legal narrative. We will briefly discuss the Dutch situation.

The Netherlands almost literally implemented the definition of trafficking as proposed by the Framework Decision in its article $273 \mathrm{f}$ Dutch Code of Criminal Law. ${ }^{12}$ The Dutch government sees the protection of individual freedom as its most important aim. Adults - Dutch or foreign - can legally work as prostitutes when they have a working permit, have come to the Netherlands of their own volition and work for a brothel owner who sticks to the laws and regulations of the sector. Here, foreign women who work in the legal prostitution business are supposed to be able to make their own decisions and are not necessarily perceived as victims - at least on paper, in the legal narrative.

Exploitation is a central element in the Dutch definition of trafficking; if the perpetrator abuses his power by making use of the dependant situation of the victim, this is qualified as exploitation. If the perpetrator abuses the poor financial circumstances of the victim or the fact that the victim illegally entered the country, this is held against him by Dutch law. As is required by the Framework Decision, the consent of the victim to being exploited is irrelevant, as is her or his history in prostitution. All links in the trafficking chain - recruiters, individuals who organise the transport, forge identity papers, control the victims, club owners, in short: everyone who profits from the trafficked person - can be prosecuted and punished for trafficking.

\section{The Dutch enforcement narrative: 'They are better informed than we are'}

The flyer with the invitation to the thematic meeting of the "Task Force Human Trafficking" 13 - established by the Minister of Justice and aiming at signalling and tackling obstacles in the implementation of anti-trafficking policies and spreading

\footnotetext{
${ }^{12}$ This is quite different, for example, in the United Kingdom, where the definition of trafficking for the purpose of sexual exploitation (in the Sex Offences Act, paragraph 57-59) seems to be unrelated to the Framework Decision, and focuses mainly on preventing illegal immigration for the purpose of prostitution.

${ }^{13}$ Leiden, Holiday Inn Hotel, October 29, 2009
} 
best enforcement practices - did not leave any doubt as to how the organizers wanted the public to perceive human trafficking. The picture on the front shows a pretty young woman with fear in her big, blue eyes and her mouth covered by a dark, hairy, male hand. It presents an obvious combination of stereotypes: the powerless, female victim, ethnically similar (or close) to the public attending the meeting, dominated by the cruel, foreign man, perhaps her pimp, who will do anything to stop her from telling her heartbreaking story of exploitation, violence and loneliness. More metaphorically thinking, the image pictures the perpetrator as being in control and ruling the trafficking situation with a strong hand. The stereotypes expressed in the invitation flyer prevailed during the meeting, which was attended by hundreds of specialists in human trafficking, including police officers, lawyers, public prosecutors and social workers.

Why do such stereotypes exist and why are they repeatedly enforced, even though most professionals do encounter, during their work, "victims" and "perpetrators" who do not live up to the image? In the Dutch case, such images legitimize the distribution of tasks between law enforcers and social welfare institutions. They direct national law enforcement responses and the kind of law enforcement instruments to be used; the more "evil" the perpetrator is imagined, the more harsh and far-reaching instruments may be employed. However, the image of a strong opponent and complex criminal networks can also result in decisions not to pursue a trafficking case at all, as we will show in this section.

The stereotypical image of a trafficking situation suggests a dichotomy in which victims and perpetrators can be clearly recognized as each other's opposites. This image reflects the enduring struggle between the proponents of a repressive (law enforcement) versus a human rights approach to trafficking. While the human rights approach focuses on victims and their need for special protection, the law enforcement approach strives primarily for the repression of perpetrators, facilitators et cetera. Several authors perceive these approaches as contradictory and often being in conflict (Kempadoo 2005: xiv; O'Connell Davidson 2005: 69; Friman and Reich 2007; Mertus and Bertone 2007), but the Dutch Ministry of Justice's officials and the representatives of the police picture a more complementary relationship: the human rights approach is perceived as necessary and useful (and is therefore partly financed by the government), but first and foremost an NGO and social welfare organization's concern. The repression and pursuit of offenders by law enforcement principles, then, is the task of the government police. The human rights approach is thereby not disqualified in Dutch policies on trafficking; however, law enforcers and policy makers generally do experience a clear hierarchy between the two tasks: repression comes first.

The emphasis on repression in Dutch law enforcement implies that the main goal of police activities is to detect and prosecute perpetrators of human trafficking. Generally, therefore, the primary focus is on offenders of human trafficking - not on victims, as a Royal Netherlands Marechaussee group leader of the Human Trafficking and Human Smuggling Expertise Centre explained:

'The police remain mainly interested in fighting crime, (that is...) organized crime, so they are chiefly interested in the perpetrators ${ }^{, 14}$

\footnotetext{
${ }^{14}$ Interview with the Royal Netherlands Marechaussee Teamleader of the Human Trafficking and Human Smuggling Expertise Centre, Utrecht, September 30, 2009.
} 
The police's assessment of the possible successfulness of the eventual trial, and the eventual participation of victims therein, might sometimes conflict with the trafficked persons' own interests. NGOs and social welfare organizations in the Netherlands complain about the lack of interest by some police forces in accepting notifications by victims of the facts perpetrated by their traffickers and/or their pleas for legal protection (Boermans 2009). In the expert meeting of the Advisory Committee on Migration Policy ${ }^{15}$ it was stated that police decisions not to follow up notifications by victims were often made too quickly and were grounded on insufficient information. When a case - and the trafficked person concerned, included - is considered as interesting from a criminal investigative point of view, an investigation might be initiated. If not, a complaint is not filed as human trafficking (but as another criminal act) or it is not filed (and not dealt with) at all. The value of victim testimonies in a criminal lawsuit is, moreover, limited, according to a police superintendent of the Expertise Centre, ${ }^{16}$ who stated that the police will generally not rely on these testimonies, as they will often not stand up in court. Witnesses do not always tell the (whole) truth - whether because they themselves are implied in the act of trafficking, or because they are afraid of repercussions - and therefore other forms of intelligence (telephone taps, investigating financial transactions et cetera) are used to successfully bring the case to court. In short, we conclude that Dutch law enforcement imaginaries of "victims" are inspired by legal pragmatics: "victims" are considered useful and are given police attention if they can contribute to the lawsuit. If not, they are not considered at all - that is, not by the Dutch police. $^{17}$

On the other side of the coin, perpetrators of human trafficking for the sex industry are imagined by Dutch police functionaries as being organized in complex, transnational networks with ruthless business morals and smooth and rapid lines of internal communication. A police inspector illustrated this image:

'They know very well when we have an activity [police operation], and they will sacrifice one of their girls, and move the others quickly to another place. (...) They are better informed than we are. They are well organized and if they see us controlling one window in the red light district, they immediately make a phone call to inform the criminal group ${ }^{18^{\prime}}$

Human trafficking crime networks are perceived to be very mobile; they easily operate across borders, as the same inspector remarked:

'Pimp networks go to the places where they can operate with the least restraint (...) and will change locations whenever laws or law enforcement methods become less favourable for them'

\footnotetext{
${ }^{15}$ See: Verslag Expertmeeting VN-Vrouwenverdrag en het Nederlandse Vreemdelingenbeleid en -recht, September 2002.

${ }^{16}$ Expert meeting entitled "Human Trafficking Imagined", Willem Pompe Institute of Criminal Law and Criminology, Utrecht, May 14, 2009.

${ }^{17}$ Recent studies conclude that in the USA, current law-enforcement strategies probably discourage victims' reporting to the police, as one-fifth of the law enforcement agencies frequently deport identified victims (Mattar and Van Slyke 2010: 197).

${ }^{18}$ Police inspector at the expert meeting "Human Trafficking Imagined", Willem Pompe Institute of Criminal Law and Criminology, Utrecht, May 14, 2009.
} 
It is remarkable that the stereotypical image of perpetrators in the legal narrative and the idea that human trafficking is a very serious crime, committed by organized, transnational networks which should be taken seriously by the police, is not decisive for the Dutch police to take action. ${ }^{19}$ Police forces are reluctant to take up trafficking cases, due to being overburdened with criminal cases of all kinds. The complicated nature of criminal investigations against traffickers is a significant factor here; police officers often doubt whether a case will successfully stand up in court. According to the participants in the above-mentioned expert meeting of the Advisory Committee on Migration Policy ${ }^{20}$ the network-like structures of traffickers and smugglers make it practically impossible to make a good assessment of a case just from a victim's complaint. This complexity and the related perceived risk of wasted police capacity if a case were to remain unsolved contributes to the reluctance to start an investigation. Court verdicts serve as beacons for the police in this matter. ${ }^{21}$ According to the Royal Netherlands Marechaussee Teamleader of the Human Trafficking and Human Smuggling Expertise Centre:

'Acquittals tend to lead to an adaptation of the investigative priorities of the police [e.g. to the disadvantage of human trafficking cases]. There are enough other cases to be solved! 22

Summarizing the above, the Dutch law enforcement narrative is strongly based on images of perpetrators as being organized in complex, mobile, transnational and well informed crime groups, which are extremely "hard to get". The attention paid to victims in Dutch policies and the government funding of NGOs and social welfare institutions assisting victims softens the consequences of repressive policies and "tough" law enforcement resulting from that narrative, but simultaneously underscores the stereotype images of innocent, helpless victims in need of protection. The law enforcement narrative thereby upholds and underscores the stereotypical image of trafficking as being characterised by at least three clearly recognizable and easily definable parties: the innocent and helpless victim, the powerful, evil, octopus-like trafficker's organisation and the goodwilling but rather impotent law enforcer.

Surprisingly, this narrative does not (generally) inspire the Dutch police institution to fiercely go after these "evil", mobile, criminal networks, simultaneously manifesting their own authority and power. They are reluctant to engage the enemy due to two reasons: a work load which is too heavy and many other priorities, on the one hand, and severe risks of losing a case, given the complexities of criminal

\footnotetext{
${ }^{19}$ Farrell et al. (2010) observed that in the USA local

${ }^{20}$ See note 11

${ }^{21}$ An example of such a complicated international trafficking case was the so-called 'Koolvis case'. In this Dutch police investigation, which took almost two years and which was pioneering in international law enforcement cooperation, a criminal network was targeted with branches in the Netherlands, Nigeria, Italy, France, Belgium, Spain and Great Britain. A total of 24 suspects were arrested in several European countries on the 24th of October 2007. Even though the case brought many criminal network members successfully to justice, Dutch police officials involved in the investigation were disappointed about the outcome. A number of suspects could not be convicted of trafficking (only of smuggling). The statements by the victims were excluded as evidence because of improper police registration and insufficient monitoring by the public prosecutor.

${ }^{22}$ Interview with the Royal Netherlands Marechaussee Teamleader of the Human Trafficking and Human Smuggling Expertise Centre, Utrecht, September 30, 2009.
} 
investigations in this field, on the other. This leads to a paradoxical result: images of victims and perpetrators in existing legal and law enforcement narratives in practice seem to discourage, rather than encourage efficient law enforcement activities in the Netherlands. It may be useful, then, to reconsider the myths of "vulnerable victims" and "potent, complexly organized perpetrators" that steer policing in such unforeseen directions.

\section{The ethnographic narrative: heterogeneous traffickers and informed victims}

'I don't know anyone here who ever thought they were going to be a waitress... those women must be somewhere else, I have never met one... Anyway being a waitress in Albania is just like being a "waitress" in Italy or Greece... serve in the front room, fuck in the back room.... (...) So anyone who is going to be a waitress in the West knows what that means... we are not stupid' (Davies 2009: 154-155)

The above citation, which is a compilation of statements by two informants in the ethnographic research by John Davies (2009) on Albanian women in Lyon's (France) sex industry, contradicts the popular image of innocent, clueless, helpless and deceived victims. As several empirical studies have shown (e.g. Siegel and Bovenkerk 2000; Siegel and Yesilgoz 2003; Siegel 2005; Agustín 2007; Janssen 2007; Brunovskis and Surtees 2008; Davies 2009) most of the trafficked women do not identify themselves as victims and especially not in the sense of an innocent, passive and ignorant individual (O'Connell Davidson 2005), even though aspects of coercion and deceit are relevant. These studies show that the decisions to "migrate" were often well considered and that the women feel responsible for their own choices and actions, regardless of the outcome. Moreover, a large number of women knew beforehand what their work in the destination country would imply or, at least, they were aware of the risk of becoming involved in sex work. In fact, the women who do feel deceived do not complain about their work being sexual per se, but about (exploitative) working conditions which deviate from the agreements made earlier. Here it should also be noted that some of the women already worked as prostitutes in their home countries (Aronowitz 2009; Agustín 2007; Janssen 2007). The relatively large amount of money earned and the related independence turn out to be important reasons why women decide to continue with sex work, even after having paid off their debts (Agustín 2007; Long 2004; Skilbrei and Tveit 2008; Siegel 2007).

The stereotypical image of victims of trafficking is thus too narrow, unjustly suggesting that the experiences of all victims are alike and that all victims have similar backgrounds. Empirical studies contradict such images (see also: Oude Breuil 2008; Roos 2008; Siegel and Yesilgoz 2003; Siegel and de Blank 2008). Firstly, the assumption that the group of victims is "explicitly gendered" and that trafficking only "happens" to women and children (whereas men are considered to be the active actors, whether as traffickers, as smugglers or as illegal migrants deciding to be smuggled), should be refuted. Men can be victims of trafficking as well, just as women may be perpetrators, as Siegel and De Blank (2008) have clearly 
shown in their study on Nigerian "Madams" organizing human trafficking in Nigerian girls in the Netherlands (see also Becucci 2008). Secondly, we cannot confirm from ethnographic studies that all victims have the same poor socio-economic backgrounds. Targets of recruitment 'are not limited to the poorly educated or desperately impoverished' (Europol 2006: 18). In the Ukraine and Russia, for example, well educated individuals from urban areas are more likely to be recruited because of their knowledge of foreign languages and their willingness and ability to leave the country and find a job abroad (Corrin 2005; Europol 2006). The ethnographic narratives, moreover, show that there may be reasons other than economic reasons for wanting to "migrate", whereby aspects like adventure, opportunities and independence play just an important role (Agustín 2005; Corrin 2005; Europol 2006). According to these studies, human trafficking for sexual exploitation might rather be approached as an aspect of a (more and more common) migration strategy - even if most women were not aware of the possible exploitation, nor of the dangers involved in sex work, when deciding on this strategy.

The victim/perpetrator dichotomy presumed in the legal and enforcement narratives does not correspond to the more complex reality either. Empirical studies show that these separately constructed categories are, in fact, often intertwined; victims and perpetrators are not necessarily opponents. Victims can become perpetrators or facilitators by taking an active role at some point in the trafficking process, which was the case in Norway in 2004, where Nigerian women were entering the prostitution market. At first glance there seemed to be no pimp and the group of women seemed to consist of friends. It was only after a while that law enforcers realized that the pimp had been replaced by a "madam" who had been a prostitute herself (Skilbrei and Tveit 2008; see also: Siegel 2007). Sometimes, women who started off as victims of trafficking later became recruiters in an attempt to pay off their debts, thereby victimizing others (Siegel 2007). The fact that the women are often involved in a love affair with the perpetrator (Bovenkerk et al. 2006) confirms this merging of the socially constructed categories of "victims" and "perpetrators"; the idea of both parties being each other's opponents can then be refuted as well.

As far as imageries of perpetrators are concerned, we can conclude that there are significantly fewer studies on the perpetrators of human trafficking for sexual exploitation than there are on victims (see also: Zhang 2009). However, several studies show that even though there is evidence that trafficking in some parts of the world is committed by organized crime gangs, the knowledge is too scarce to validate the idea that trafficking is generally organized in large, complex, transnational crime networks (Sanghera 2005: 15; Segrave et al. 2009: 10; Siegel 2005). Ethnographical fieldwork shows that in Bulgaria, for example, trafficking networks are often rather small, localized in only about ten Bulgarian cities and not necessarily characterized by smooth and rapid lines of communication (as the enforcement narrative suggests). ${ }^{23}$ Even the entire trafficking chain can be contained

\footnotetext{
${ }^{23}$ Presentation by Philip Gounev (Center for Study of Democracy, Sofia) at the expert meeting "Human Trafficking Imagined", Willem Pompe Institute of Criminal Law and Criminology, Utrecht, May 14, 2009.
} 
within a limited regional context, as is the case in the so-called "lover boy" phenomenon in the Netherlands (Bovenkerk et al. 2006). ${ }^{24}$

A striking finding in several empirical studies (Siegel and Bovenkerk 2000; De Wildt 2007; Brunovskis and Surtees 2008) is that prevailing images of victims, used by law enforcers and aid groups, are strategically used by prostitutes who are, or are not trafficking victims, in order to claim aid and rights in the destination countries. Sex workers in search of assistance present themselves as victims and make an effort to live up to the expectations implicit in the victim imagery of the welfare institution, as is illustrated by Brunovskis and Surtees (2008: 59): 'one woman described how her appearance as "a good girl" evidenced by clothing, behavior and demeanor made her believable, and consequently, eligible for assistance (...)'. In Italy, De Wildt (2007) observed that when asking for protection and aid from the International Organization for Migration, women working in prostitution would emphasize that they were not aware of the kind of job they were going to do before they came to Rome, suggesting that they had been deceived; when confronted by the police they shifted their presentation to that of a strong and independent woman, in order to be acquitted as soon as possible and be able to continue working. In short, they recounted and manipulated their "productive life histories" (De Wildt 2007) rather than telling "true stories".

On the other hand, perpetrators strategically use legal and enforcement images of them as well. As several authors have shown for other forms of organized crime, existing narratives on "criminals" often serve as examples to criminals and their obscure images may well serve as a scare tactic (see: Bovenkerk 2001: 46-50; Bovenkerk et al. 2003).

Stereotypical images of trafficking victims and perpetrators may become selfproclaiming truths, as the individuals to whom the labels are applied might make efforts to live up to the imagery, which may have advantages for them in specific situations, or in other words, 'if men define situations as real, they are real in their consequences' (Thomas and Thomas 1928: 572).

In comparison to the legal and the law enforcement narratives the ethnographic narrative has, in short, three things to add. In the first place, we cannot be certain that trafficking networks are omnipotent, transnational and (well) organized, the members of which are better informed than law enforcement functionaries - they may also be small, rather unorganized, locally embedded networks that operate in only one or a few European cities. Secondly, women's agency plays an important role in the lived experiences of trafficking victims even though this aspect is more or less neglected in legal and law enforcement narratives. Thirdly, victims and perpetrators are not just the objects of labelling processes and stereotyping; they strategically deploy prevailing images in order to reach their goals.

\footnotetext{
${ }^{24}$ The Dutch have somewhat confusingly adopted the English term "lover boy" to denote a young man who deliberately seeks out and enters into a relationship with a young teenage girl in order to specifically entice her into prostitution.
} 


\section{Conclusion and discussion}

In this contribution three narratives on human trafficking for the sex industry have been analyzed: the (international and national) legal narrative, the (Dutch) law enforcement narrative and the ethnographic narrative. The imaginations concerning "victims" and "perpetrators" in the legal and law enforcement narratives significantly diverge from those in the ethnographic narrative. This diversity, we argue, can be explained by the fact that narratives are not neutral descriptions of the social problem of human trafficking but reflect the needs, problems and interests of the settings from which they originated.

In the international legal narrative, for example, lobbying groups have had an important impact on the legal definition of trafficking and the imaginations of "victims" and "perpetrators" therein. Where neo-conservative and feminist lobbying groups strongly influenced the image of "victims" of trafficking, emphasizing the vulnerability of women and children and their subordination in all situations of prostitution, proponents of the "war on organized crime" had a strong say in the imagination of the "perpetrators" of trafficking as transnational organized crime groups, thereby securing government funding and public backing for repressive (international) law enforcement policies. It is therefore important to distinguish political motivations from empirical observations in the imaginations of human trafficking for the sex industry.

When such international legal narratives - in which political motives, empirical data and analytical insights are intertwined - are being translated into nation policies, the content changes because of local, culturally-specific perceptions of prostitution, trafficking, migration and legal traditions. We saw, for example, how "victims" are, in principle, supposed to be able to make an informed choice to prostitute themselves in the Netherlands; their prostitution work is not considered to be forced per se, whereas in the United Kingdom a foreign prostitute is presupposed to be "exploited". We therefore deem it important to conduct (cultural) criminological research into national differences in the implementation of international laws and regulations, thereby paying due attention to the impact of cultural differences and the legal traditions of nation states on the pragmatics of trafficking policies.

From the Dutch case study on the enforcement narratives we conclude that international and national legal imageries become encrusted in enforcement practices in sometimes contradictory ways. Pragmatic considerations may result in (ideological) policy principles being cast aside: in Dutch law enforcement praxis, legal imageries of potent, transnational organized crime groups and the ideological principle to fiercely combat such crime networks did not automatically lead to an efficient "tackling" of the problem, but rather discouraged police forces from investing energy and personnel in the investigation and prosecution of trafficking networks. The (national and international) legal imageries that inspired such ideological and political policy principles - to be more precise: the stereotypical, binary images of the helpless victim and the omnipotent, evil trafficker - hampered, rather than helped to combat human trafficking for the sex industry.

This obstacle might be overcome if the legal and enforcement narratives would profit more from the bottom-up, empirical narrative. The latter could de-mystify the often rather abstract, legal narrative, "ground" the enforcement narrative and put the 
strong emphasis on repression into perspective. The ethnographic finding that "victims" are not all helpless, clueless, uninformed, weak, vulnerable et cetera might shift the attention from the repressive obsession with determining whether a trafficked person is a "victim" or an "illegal migrant", an untrustworthy witness or a useful accessory in a lawsuit, to the far more important question of what made trafficked persons (want to) leave there homesteads and fall into the hands of trafficking networks in the first place. It may, in other words, turn our attention to structural causes of (forced) migration and trafficking that are still given little political attention.

The ethnographic narrative further tells us that, as of now, we cannot confirm that trafficking networks are directly linked to omnipotent, transnational organized crime groups. Instead of (the legal and law enforcement narratives') presumptions about these strong, "evil" networks, further empirical research could establish what trafficking groups really look like - their size, motivations, the measure of the organization, the method for making transnational connections, the kind of force used to make trafficked persons comply et cetera. By exchanging and counter-checking imageries from all three narratives, we may develop a shared understanding of sex trafficking as non-binary, non-normative, heterogeneous and embedded in specific, local circumstances - those of "sending" as well as "receiving" countries. This may lead to an approach that is less ideological and volatile, and inspires and encourages grounded, realistic and locally adapted enforcement practices.

Open Access This article is distributed under the terms of the Creative Commons Attribution Noncommercial License which permits any noncommercial use, distribution, and reproduction in any medium, provided the original author(s) and source are credited.

\section{References}

Agustín L (2005) Migrants in the Mistress's house: other voices in the trafficking debate. Soc Polit 12 (1):96-117

Agustín L (2007) Sex at the margins: migration, labour markets and the rescue industry. Zed Books, London

Akofa H (2000) Une esclave moderne. Éditions Michal Lafon, Neuilly-sur-Seine

Aronowitz A (2009) Human trafficking, human misery: the global trade in human beings. Praeger, Westport

Becker (1991 [1963]) Outsiders. Studies in the construction of deviance. New York: The Free Press

Becucci S (2008) New players in an old game: the sex market in Italy. In: Siegel D, Nelen H (eds) Organised crime. Culture, markets and policies. Springer, Dordrecht, pp 57-70

Boermans B (2009) Uitgebuit en in de bak! Slachtoffers van mensenhandel in vreemdelingendetentie. Amsterdam: BLiN - Humanitas/Oxfam Novib. Retrievable at: http://www.blinn.nl/images/uploads/ Reports/Uitgebuit_en_in_de_bak.pdf

Bovenkerk F (2001) Misdaadprofielen. Meulenhoff, Amsterdam

Bovenkerk F, Siegel D, Zaitch D (2003) Organized crime and ethnic reputation manipulation. Crime Law Soc Change 39(1):23-38

Bovenkerk F, van San M, Boone M, Boekhout van Solinge T, Korf D (2006) Loverboys of modern pooierschap. Uitgeverij Augustus, Amsterdam

Brunovskis A, Surtees R (2008) Agency or illness - the conceptualization of trafficking: victims' choices and behaviors in the assistance system. Gend Technol Dev 12(1):53-76

Corrin C (2005) Transnational road for traffic: analysing trafficking in women from and through Central and Eastern Europe. Eur Asia Stud 57(4):543-560 
Davies J (2009) 'My name is not Natasha'. How Albanian Women in France use trafficking to overcome social exclusion (1998-2001). Amsterdam University Press, Amsterdam

Ditmore M (2005) Trafficking in lives: how ideology shapes policy. In: Kempadoo K (ed) Trafficking and prostitution reconsidered: new perspectives on migration, sex work and human rights. Paradigm Publishers, Boulder, pp 107-126

Edwards A, Gill P (2002) The politics of 'transnational organized crime': discourse, reflexivity and the narration of 'threat'. Br J Polit Int Relat 4(2):245-270

Europol (2006) Trafficking of women and children for sexual exploitation in the EU: the involvement of Western Balkans Organised Crime 2006. Crimes Against Persons Unit. Retrievable at: http://www. europol.europa.eu/publications/Serious_Crime_Overviews/Western_Balkans_THB_Threat_Assessment. PDF

Farrell A, McDevitt J, Fahy S (2010) Where are all the victims? Understanding the determinants of official identification of human trafficking incidents. Criminol Public Policy 9(2):201-233

Friman HR, Reich S (2007) Human trafficking and the Balkans. In: Friman HR, Reich S (eds) Human trafficking, human security, and the Balkans. University of Pittsburgh Press, Pittsburgh, pp 1-20

Haveman R (1998) Voorwaarden voor de strafbaarstelling van vrouwenhandel. Gouda Quint, Deventer

Herz AL (2005) Menschenhandel; eine empirische Untersuchung zur Strafvervolgungspraxis. Dunker and Humbold, Berlin

Janssen M (2007) Reizende sekswerkers: Latijns-Amerikaanse vrouwen in de Europese prostitutie. Het Spinhuis, Amsterdam

Kapur R (2005) Cross-border movements and the law: renegotiating the boundaries of difference. In: Kempadoo K (ed) Trafficking and prostitution reconsidered: new perspectives on migration, sex work and human rights. Paradigm Publishers, Boulder, pp 25-42

Kempadoo K (2005) Trafficking and prostitution reconsidered: new perspectives on migration, sex work and human rights. Paradigm Publishers, Boulder

Long LD (2004) Anthropological perspectives on the trafficking of women for sexual exploitation. Int Migr 42(1):6-29

Mam S (2005) Le silence de l'innocence. Editions Anne Carrière, Paris

Mattar M, Van Slyke S (2010) Editorial introduction: identifying human trafficking victims. Improving our approach to human trafficking. Criminol Public Policy 9(2):197-200

Mertus, Bertone (2007) Combating trafficking: international efforts and their ramifications. In: Friman HR, Reich S (eds) Human trafficking, human security, and the Balkans. University of Pittsburgh Press, Pittsburgh, pp 40-60

Moore SF (2005) Law and anthropology. A reader. Blackwell Publishing, Malden

O'Connell Davidson J (2005) Children in the global sex trade. Polity, Cambridge

Oude Breuil BC (2008) Precious children in a heartless world? The complexities of child trafficking in Marseille. Child Soc 22(3):223-234

Outshoorn (2005) The political debates on prostitution and trafficking of women. Soc Polit Int Stud Gend State Soc 12(1):141-155

Roos L (2008) Weibliche Körper im Fluss des Globalen Kapitalismus. Masterthesis Utrecht University, Straatprostituees in Berlijn

Sanghera J (2005) Unpacking the Trafficking Discourse. In: Kempadoo K (ed) Trafficking and prostitution reconsidered: new perspectives on migration, sex work and human rights. Paradigm Publishers, Boulder, pp 3-24

Segrave M, Milivojevic S, Pickering S (2009) Sex trafficking. International context and response. Willan Publishing, Devon

Siegel D (2005) Recent trends in women trafficking and voluntary prostitution: Russian-speaking sexworkers in the Netherlands. Transnational Crime 4(1):4-23

Siegel D (2007) Nigeriaanse madams in de mensenhandel in Nederland. Justitiële Verkenningen 33(7):39-49

Siegel D, Bovenkerk F (2000) Crime and manipulation of identity among Russian-speaking immigrants in the Netherlands. J Contemp Crim Justice 16(4):424-444

Siegel D, De Blank S (2008) Vrouwen die in vrouwen handelen. De rol van vrouwen in criminele netwerken. Tijdschrift voor Criminologie 50(1):35-48

Siegel D, Yesilgoz Y (2003) Natashas and Turkish men: new trends in women trafficking and prostitution. In: Siegel D, Van de Bunt H, Zaitch D (eds) Global organized crime. Trends and developments. Kluwer Academic Publishers, Dordrecht, pp 73-84

Skilbrei ML, Tveit M (2008) Defining trafficking through empirical work: Blurred boundaries and their consequences. Gend Dev Technol 12(1):9-30

Taylor C (2002) Modern social imaginaries. Public Cult 14(1):91-124 
Thomas WI, Thomas DS (1928) The child in America: behaviour problems and programs. Knopf, New York

Weitzer R (2007) The social construction of sex trafficking: ideology and the institutionalization of a moral crusade. Polit Soc 35(3):447-475

Wildt Rde (2007) Tasten in het duister: een studie naar de handelingsmogelijkheden van Roemeense straatprostituees in Rome. Masterthesis Utrecht University.

Zhang SX (2009) Beyond the "Natasha" story - a review and critique of current research on sex trafficking. Glob Crime 10(3):178-195 